\title{
Pineal Region Meningioma
}

National Cancer Institute

\section{Source}

National Cancer Institute. Pineal Region Meningioma. NCI Thesaurus. Code C6756.

A meningioma that affects the pineal gland. 